American Journal of Pharmaceutical Education 2017; 81 (5) Article 83.

\title{
COMMENTARY
}

\section{Is Lecturing Obsolete? Advocating for High Value Transformative Lecturing}

\author{
Therese I. Poirier, PharmD, MPH \\ Southern Illinois University Edwardsville, Edwardsville, Illinois \\ Submitted November 2, 2016; accepted November 16, 2016; published June 2017.
}

Keywords: lecturing, transformative

The main instructional strategy used in schools and colleges of pharmacy today is still probably lecturing. ${ }^{1}$ However, during the past decade, the emphasis started to shift away from teacher-centered models such as lecturing to student-centered teaching, including use of active learning techniques. Even the Accreditation Council for Pharmacy Education (ACPE) standards in 2007 advocated for the use of active learning strategies and other high level pedagogical strategies and the 2016 standards advocate for teaching/learning methods that actively engage learners, promote self-directed learning and foster collaborative learning. ${ }^{2-3}$

The shift from lecturing to strategies such as flipped classrooms, peer-led teaching, team-based learning or problem-based learning has become "pc" (pedagogical correctness). ${ }^{4}$ Technology has also been used to deliver content thus making lecturing seem obsolete in the view of some. As teachers of pharmacy, we are challenged with what is the best pedagogical approach for learning and will develop students as critical thinkers, problem-solvers and lifelong learners.

There have been many arguments in support of both lecturing and less lecturing. Advocates of lecturing say that it allows an expert to present facts and issues without a classroom filled with student opinions. It allows for graphical depiction of material. It offers students an opportunity to engage with an expert involved in discovery. It is cost-effective and suitable for large class sizes. It is an efficient way to expose students to a large amount of information (ie, "cover" more material). Some even advocate that it is the only way to "cover" foundational knowledge.

The disadvantages of lecturing are numerous and include students' boredom and decreased motivation, and less student classroom engagement. ${ }^{5}$ Students approach the class in a binge and purge manner, especially when large amounts of information are presented. ${ }^{1}$ They also do not take responsibilities for their learning. Lecturing is

Corresponding Author: Therese I. Poirier, Department of Pharmacy Practice, Southern Illinois University, Campus Box 2000, Edwardsville, IL 62026. Tel: 618-650-5155. E-mail: tpoirie@siue.edu consistent with Freire's banking concept in that it allows for transmission of information that is viewed as knowledge that is being deposited or banked. ${ }^{6-7}$ The banking concept supports the idea that by lecturing, one is not educating because students are not challenged nor engaged with the lecturer and are only asked to memorize and repeat the information.

The arguments for less lecturing, prevalent among faculty involved in instructional design, include the perceived push due to the ACPE accreditation standards, the need to accommodate a variety of learners, and the view that lecturing is not effective for significant learning as students binge and purge for exams. Millennial students are accustomed to technological stimulation and have short attention spans. Technological advances also provide numerous ways to gain information. Lecturing is focused on communication, retention and repetition of factual information. If that is the only purpose of lecturing then the call for a transformation in how content is delivered with technological advances as advocated by Blouin and colleagues would be reasonable. ${ }^{1}$

The characteristics of a quality lecture are easy to measure. Having a clear presentation, speaking slowly, planning and structuring content in a logical sequence, staying on topic, and using visual-auditory aides, including using slides with only key terms, are all characteristics of a good lecturer. Also, a lecturer who is enthusiastic, uses humor, focuses on key issues versus covering all the content, lectures for only 15- to 20-minute timeframes and is more informal are quality indicators of a good lecturer. ${ }^{8}$ Short described the concept of presentation lectures versus performance lectures. ${ }^{5}$ In presentation lectures, there is a minimal degree of class interaction, while performance lectures keep classes engaged. ${ }^{5}$ Short showed that students prefer and perform better on exams with performance lectures. However, even with these traits, it does not imply that a lecture, even if a performance one, has high educative value or is transformative.

A high educative value transformative lecture should inspire students. As William Yeats said, "education is not the filling of the pail, but the lighting of a fire." The 


\section{American Journal of Pharmaceutical Education 2017; 81 (5) Article 83.}

lecturer should be talking with students and developing an interpersonal relation. ${ }^{6}$ The lecturer should demonstrate interest in the subject and show how the subject is relevant to the world and to students. There should be critical dialogue. Students should be challenged and problems posed, with time to reflect and apply the information. Dewey advocated that information is only understood if there is reflection about it. There must be critical thinking. ${ }^{9}$ The ideal lecture should stimulate students to evaluate and think. It should challenge and cause interruptions, the so-called "art of thinking." turer should allow for pauses to allow the class to reflect on content and allot time to problem solve. Webster advocated that the lecture cannot be replicated by other learning formats. ${ }^{6}$ Vygotsky's concept of inner speech is the theory behind the transformative nature of lecturing. This concept is that when students are listening, they are interpreting the meaning of the words. This is where students are challenging the truth, critically thinking, reflecting and questioning. When students are listening, they are not just vessels but consist of attitudes, values, biases, experiences, feeling and thoughts. ${ }^{10}$

The live lecture allows for the human aspect of knowledge that online materials cannot embody. Dewey did not like the term knowledge but "warranted assertions" which implies that information is not objective and should be challenged. ${ }^{6}$ Lecturing allows time for uninterrupted presentation of arguments. Lecturing allows faculty to assist students with interpretation of information, especially with use of non-verbal expressions. The live lecture allows the lecturer to be able to gauge verbal and non-verbal expression of student understanding. Then students must have time to be alone for silent engagement when they can critically think, question and challenge the information. ${ }^{11}$ Thus, lecturing can be transformative and of high educative value. Is not the goal of education to teach students to think? Dewey advocated that the ultimate purpose of education is character-forming. ${ }^{12}$ In many respects, changes in curricula should increase emphasis on using lecturing as a transformative method and also increase emphasis on the affective, non-cognitive domains of our ACPE standards.

Lecturing that is transformative is an art and is still relevant for $21^{\text {st }}$ century pharmacy education. Lecturing should stimulate critical thinking and reflection. Thus, there should not only be a focus on innovative active learning and student-centered teaching approaches, but also a focus on the art of transformative lecturing.

\section{REFERENCES}

1. Blouin R, Joyner P, Pollack G. Preparing for a renaissance in pharmacy education: the need, opportunity, and capacity for change. Am J Pharm Educ. 2008;72(2):Article 42.

2. Accreditation Council for Pharmacy Education. Accreditation standards and guidelines for the professional program in pharmacy leading to the doctor of pharmacy degree. Guidelines 2.0. https://www. acpe-accredit.org/pdf/S2007Guidelines2.0_ChangesIdentifiedInRed. pdf. Accessed May 26, 2016.

3. Accreditation Council for Pharmacy Education. Accreditation standards and key elements for the professional program in pharmacy leading to the doctor of pharmacy degree. Standards 2016. https:// www.acpe-accredit.org/pdf/Standards2016FINAL.pdf. Accessed May 26, 2016.

4. Burgan M. In defense of lecturing. Change. 2006. http://www.ltrr. arizona.edu/fp/geog695c/PDFs/In\%20Defense\%20of\%20Lecturing. pdf.

5. Short F, Martin J. Presentation vs performance: effects of lecturing style in higher education on student preference and student learning. Psy Teach Review. 2011;17(2):71-82.

6. Webster RS. In defence of the lecture. Aust J Teach Educ. 2015;40 (10)88-105.

7. Freire P. Pedagogy of the Oppressed. $30^{\text {th }}$ Ed. New York, NY, and London, UK: Continuum International Publishing; 2000.

8. Bain K. What the Best College teachers Do.Cambridge, M. Harvard University Press; 2004.

9. Dewey J. Essays and How We Think. John Dewey the Later Works, 1925-1953. Boydston JA, ed. Carbondale \& Edwardsville: Southern Illinois University Press.

10. Mackay H. The Good Listener: Better Relationships Through Better Communication. 1998. Sydney, Australia: Pan Macmillan. 11. Heidegger M. What is Called Thinking? Tr. J.G. Gray. L968. New York, NY: Harper \& Row; 1976.

12. Dewey J. Moral Principles in Education. In: The Middle Works of John Dewey, Volume 9, 1899-1924: Democracy and Education, 1916. JA Boydston, Ed. Carbondale \& Edwardsville, IL: Southern Illinois University Press. 